\title{
Pseudo-Chilblains in a COVID-19 Patient
}

\section{Pseudo-Frieiras em Paciente com COVID-19}

Ricardo Moutinho-Guilherme ${ }^{1 *}$, Gisela Bessa²

\section{RESUMO}

O presente artigo pretende relatar um caso de manifestação dermatológica da infeção por COVID-19, auxiliando na compreensão da doença e proporcionando uma base para uma suspeita diagnóstica.

O caso em questão aborda uma paciente do sexo feminino, de 36 anos, com infeção por COVID-19 sintomática, apresentando sintomas ligeiros. Sete dias depois do início do quadro clínico, apresentou-se com lesões dermatológicas em zonas acrais bilateralmente nas mãos. Constatou-se a presença de pápulas/vesículas eritemato-violáceas em zonas dorsais extensoras dos dedos, com sinais inflamatórios locais, rash cutâneo, rubor, edema, sensação de queimadura local, prurido e dor. Presumiram-se como hipóteses diagnósticas lesões cutâneas compatíveis com pseudo-frieiras. Realizou tratamento sintomático, tendo obtido resolução completa aos 10 dias, sem sequelas posteriores. Deve-se atentar ao facto da infeção por COVID-19 se poder apresentar apenas com manifestações cutâneas, podendo servir como um indicador da doença em casos suspeitos.

PALAVRAS-CHAVE: COVID-19/complicações; Frieiras/etiologia; Manifestações Cutâneas; SARS-CoV-2

1. Medical Doctor, Family Medicine resident. Unidade de Saúde Familiar Cynthia, Agrupamento de Centros de Saúde de Sintra, Administração Regional de Saúde de Lisboa e Vale do Tejo, Portugal. 2. Medical Doctor, Family Medicine specialist. Unidade de Saúde Familiar Cynthia, Agrupamento de Centros de Saúde de Sintra, Administração Regional de Saúde de Lisboa e Vale do Tejo, Portugal.

Received/Recebido: 16/02/2021 - Accepted/Aceite: 24/03/2021 - Published online/Publicado online: 19/04/2021 - Published/Publicado: 30/06/2021

- Author(s) (or their employer(s)) and Gazeta Médica 2021. Re-use permitted under CC BY-NC. No commercial re-use. ${ }^{\circledR}$ Autor (es) (ou seu (s) empregador (es)) e Gazeta Médica 2021. Reutilização permitida de acordo com CC BY-NC. Nenhuma reutilização comercial. 


\section{ABSTRACT}

The aim of this case is to describe an example of cutaneous manifestations caused by COVID-19 infection, helping to better understand the disease and support an early clinical suspicion.

This case addresses a 36-year-old patient with COVID-19 infection, symptomatic, with mild complaints. Seven days after the start of the clinic, she exhibited dermatological lesions in the acral areas bilaterally on her hands. The presence of erythematous-violet papules/vesicles was found in the dorsal extensor zones of the fingers, with local inflammatory signs, skin rash, flushing, edema, local burning sensation, itching and pain. Pseudo-chilblains were assumed as diagnostic hypotheses. She underwent symptomatic treatment, having achieved complete resolution at 10 days, with no subsequent sequelae.

Attention should be paid to the fact that COVID-19 may present only with cutaneous manifestations, therefore these may serve as an indicator of the disease in suspected cases.

KEYWORDS: COVID-19/complications; Chilblains/etiology; SARS-CoV-2; Skin Manifestations

\section{INTRODUCTION}

Dermatological manifestations of COVID-19 (coronavirus disease 2019) are not frequent, and its true incidence is still unknown. We present a case of a patient infected with COVID-19, with dermatological lesions in the acral areas, exhibiting vesicles and pustules on painful and itchy purpuric areas. These were similar to what we commonly refer to in the clinical practice as chilblains (pseudo-chilblains).

With this article we aim to discuss this cutaneous manifestation of COVID-19, helping to better understand the disease and support an early clinical suspicion for cutaneous manifestations.

\section{CASE REPORT}

Female, 36-year-old. Previously healthy, no prior clinical history. She denies taking any medication or known drug allergies. No family history of interest in this clinical context. Smoker (15 pack-years), she works as a kindergarten teacher.

She developed COVID-19 infection, with positive detection for viral RNA in the real-time polymerase chain reaction (rt-PCR) test on nasopharyngeal exudate. Symptomatic, with complaints of odynophagia, nasal obstruction, low fever, dry cough, headache, anosmia and ageusia, medicated with paracetamol $1 \mathrm{~g}$ po for three days. She accomplished home isolation, with no cohabitants present.

Seven days after the onset of symptoms, she presented with dermatological lesions in the acral areas bilaterally on the hands ( $4^{\text {th }}$ finger of the right hand and $2^{\text {nd }}$ finger of the left hand). She was referred to the Basic Emergen- cy Service, where erythematous-violaceous papules/ vesicles in the extensor dorsal areas of the fingers were observed (Fig. 1). With local inflammatory signs, the lesions were accompanied by a skin rash, redness, edema, local burning sensation, itching and slight pain (Fig. 2). Additionally, she had diffuse erythema in the subungual area of two fingers. She denied exposure to extreme cold or heat.
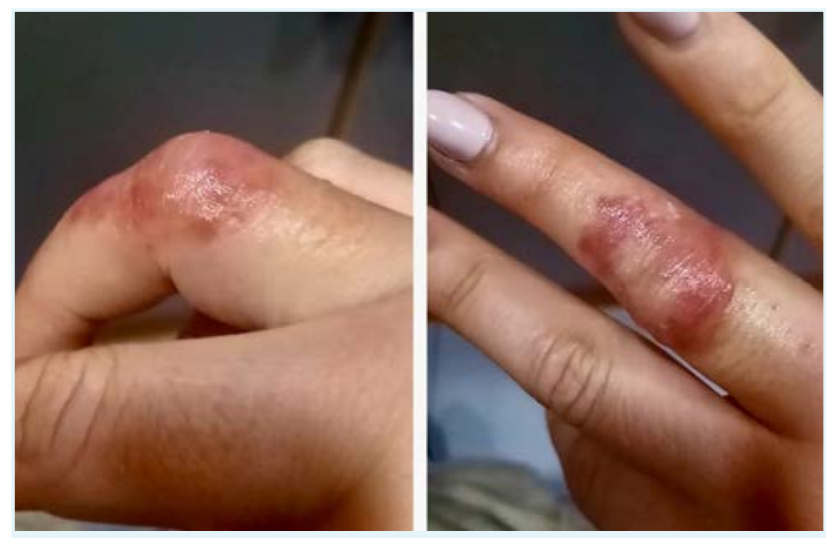

FIGURE 1. Acral areas of edema-erythema with vesicles and pustules on the right hand's $4^{\text {th }}$ finger.
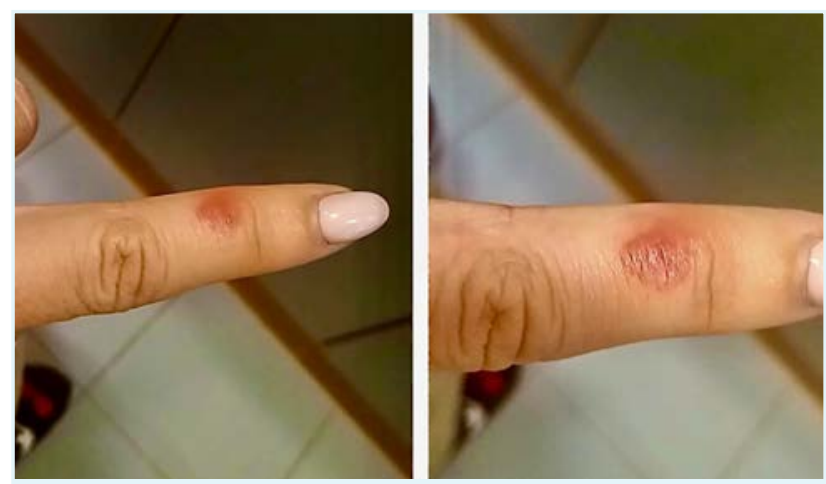

FIGURE 2. Acral areas of edema-erythema with vesicles and pustules on the left hand's $2^{\text {nd }}$ finger. 
After requesting joint observation by Dermatology, given the non-existent clinical history of the pattern in this patient and not identifying any other triggering factor, skin lesions secondary to COVID-19 infection (pseudo-chilblains) were diagnosed. The patient underwent symptomatic treatment with pentoxifylline $400 \mathrm{mg}$ po for 5 days. All lesions resolved completely within ten days, with no subsequent sequelae. There was no need for a skin biopsy.

\section{DISCUSSION}

Since COVID-19, a clinical syndrome caused by the new coronavirus, named SARS-CoV-2 (severe acute respiratory syndrome, coronavirus 2) was reported in Wuhan, China, in December 2019, 107 million people have been infected worldwide and more than 2.3 million deaths have occurred (data obtained on February $12^{\text {th }}$ 2021). ${ }^{1}$ The high rate of infection, low virulence and asymptomatic transmission of the disease promoted its rapid spread to various regions of the world, leading to the pandemic decreed by the World Health Organization (WHO) on $11^{\text {th }}$ March 2020.

The lungs are the main target organ of infection, with symptoms ranging from a common cold to severe pneumonia with breathing difficulty, in addition to the involvement of several organs or systems, leading to sepsis and septic shock with multiorganic dysfunction. ${ }^{2}$ Most described cases are asymptomatic, mild or moderate.

The dermatological manifestations of COVID-19 are uncommon, they seem to be similar to those found in other diseases of viral etiology, and its true incidence is still unknown. The first description of cutaneous findings associated with COVID-19 was made by Recalcati, ${ }^{3}$ who reported skin rashes consistent with erythematous-violet macules and papules in the acral regions, with possible formation of blisters, in $20 \%$ of patients admitted to a hospital in Italy.

Five patterns of dermatological manifestations of COVID-19 have been described, classified into maculopapular eruptions (47\%), erythema with vesicles or pustules in acral areas (pseudo-chilblains) (19\%), urticarial lesions (19\%), other vesicular eruptions (9\%) and livedo or necrosis (6\%). ${ }^{4}$

In this article, we describe a clinical case of a patient with dermatological lesions in the acral areas, adopting the appearance of vesicles or pustules, with asymmetrical, painful and itchy purple areas. These were accompanied by a burning sensation in the affected places and were similar to what we commonly refer to in the clinical practice as chilblains. These lesions frequently affect younger patients ${ }^{4}$ and are usually self-limiting or resolved with a symptomatic therapeutic course.

The pattern of pseudo-chilblains is characterized by an appearance of purpuric lesions on the hands and/or feet, with a late development in the evolution of COVID-19 disease. Fifty nine percent of patients appear with these lesions after all other symptoms. ${ }^{4}$ The severity of COVID-19 disease tends to be less acute in patients with this type of skin lesions, with a course of mild to moderate severity (without the need for hospital admission). Only $1.4 \%$ of patients with pseudo-chilblains associated with COVID-19 had a history of previous chilblains, and there seems to be a trend towards the presence of family clusters. $^{4}$

Several studies have shown that the COVID-19 virus enters cells through angiotensin-converting enzyme 2 (ACE2) receptors, which are widely expressed in the vascular endothelium, respiratory epithelium, alveolar monocytes and macrophages. ${ }^{5}$ During the course of the disease, the virus generates a widespread damage, through a secondary viremia, against target organs that express ACE2 receptors, namely the heart, kidneys, gastrointestinal tract and distal vasculature. ${ }^{6}$ This viral dissemination process occurs mainly around the second week after the onset of the disease.

It has been observed in several organs of COVID-19 patients, a pathophysiological process of degeneration and necrosis of parenchymal cells, vasoconstriction and formation of hyaline microthrombi in small vessels. ${ }^{7}$ This underlying micro-ischemic process may be the pathophysiological mechanism in cases similar to that of the described patient.

In conclusion, attention should be paid to the fact that COVID-19 can be asymptomatic, from a respiratory point of view, up to 14 days after infection, and it is possible that skin manifestations may serve as an indicator of the disease. ${ }^{8}$

\section{ACKNOWLEDGMENTS/ AGRADECIMENTOS}

We would like to thank the patient described in this clinical case, who promptly made herself available for her clinical history to be analyzed and published, fulfilling all the criteria of professional confidentiality, on behalf of medical information dissemination and mutual assistance with other patients with similar clinical findings. 
We would also like to recognize the Unidade de Saúde Familiar Cynthia, in Sintra, for the conditions offered to explore in detail all clinical cases of interest and improvement in the approach of our patients.

Additionally, we recognize all other colleagues involved in the critical review of this article, for the suggestions, spelling and linguistic correction and clear explanation of the final text.

\section{RESPONSABILIDADES ÉTICAS}

CONFLITOS DE INTERESSE: Os autores declaram a inexistência de conflitos de interesse na realização do presente trabalho.

FONTES DE FINANCIAMENTO: Não existiram fontes externas de financiamento para a realização deste artigo.

CONFIDENCIALIDADE DOS DADOS: Os autores declaram ter seguido os protocolos da sua instituição acerca da publicação dos dados de doentes.

CONSENTIMENTO: Consentimento do doente para publicação obtido.

PROVENIÊNCIA E REVISÃO POR PARES: Não comissionado; revisão externa por pares.

\section{ETHICAL DISCLOSURES}

CONFLICTS OF INTEREST: The authors have no conflicts of interest to declare.

FINANCING SUPPORT: This work has not received any contribution, grant or scholarship.

CONFIDENTIALITY OF DATA: The authors declare that they have followed the protocols of their work center on the publication of data from patients.

PATIENT CONSENT: Consent for publication was obtained.

PROVENANCE AND PEER REVIEW: Not commissioned; externally peer reviewed.

\section{REFERENCES}

1. World Health Organization (WHO). Coronavirus disease (COVID-19) outbreak situation. Geneva: WHO [Internet]; 2020; [accessed 2021 Feb 12]. Available from: http://covid19. who.int.

2. Gao Z, Xu Y, Sun C, Wang X, Guo Y, Qiu S, et al. A systematic review of asymptomatic infections with COVID-19. Microbiol Immunol Infect. 2021;54:12-6. doi: 10.1016/j. jmii.2020.05.001.

3. Recalcati S. Cutaneous manifestation in COVID-19: a first perspective. J Eur Acad Dermatol Venereol. 2020;34:e212-3. doi: 10.1111/jdv.16387.
4. Galván Casas C, Català A, Carretero Hernández G, Rodríguez-Jiménez P, Fernández-Nieto D, Rodríguez-Villa Lario A, et al. Classification of the cutaneous manifestations of COVID-19: a rapid prospective nationwide consensus study in Spain with 375 cases. Br J Dermatol. 2020;183:71-7. doi: 10.1111/bjd.19163.

5. Cao W, LiT. COVID-19: towards understanding of pathogenesis. Cell Res. 2020;30:367-9.

6. Black J, Cuddigan J. Skin manifestations with COVID-19: the purple skin and toes that you are seeing may not be deep tissue pressure injury. WCET J. 2020;40:18-21.

7. Alramthan A, Aldaraji W. Two cases of COVID-19 presenting with a clinical picture resembling chilblains: first report from the Middle East. Clin Exp Dermatol. 2020;45:746-8. doi: 10.1111/ced.14243.

8. Relvas M, Calvão J, Oliveira R, Cardoso JC, Gonçalo M. Manifestações cutâneas associadas à COVID-19. Acta Med Port. 2021;34:128-36. doi: 10.20344/amp.14574. 